\title{
EQUiLIBRIUM
}

Quarterly Journal of Economics and Economic Policy

2014 VOLUME 9 ISSUE 3, September

p-ISSN 1689-765X, e-ISSN 2353-3293

www.economic-policy.pl

Mosionek-Schweda M. (2014), The Use of Discriminant Analysis to Predict the Bankruptcy of Companies Listed on the NewConnect Market, "Equilibrium. Quarterly Journal of Economics and Economic Policy", Volume 9, Issue 3, pp. 87-105, DOI: http://dx.doi.org/10.12775/EQUIL.2014.019

\author{
Magdalena Mosionek-Schweda*
}

University of Gdansk, Poland

\section{The Use of Discriminant Analysis to Predict the Bankruptcy of Companies Listed on the NewConnect Market}

JEL classification: $B 16, G 17, G 33$

Keywords: discriminant models; Altman's model; NewConnect; bankruptcy

\begin{abstract}
The aim of this article is to analyze and evaluate the usability of discriminant models in predicting bankruptcy for companies listed on NewConnect. This market was established in 2007 and operates as an alternative trading system next to Warsaw Stock Exchange S.A., which in practice means that its regulatory regime in relation to issuers and listed companies is not as strict as the one applicable to the main market, therefore shares of small and medium-size businesses, including start-ups, can be listed on NewConnect. In this paper, discriminant models are used to analyse the financial situation of four companies removed from trading on NewConnect due to bankruptcy, Perfect Line S.A., Promet S.A., InwazjaPC S.A. and Budostal-5 S.A. The analysis is based on three models: Altman's model for emerging markets, as well as two models of the highest predictive ability according to P. Antonowicz's research, $\mathrm{ZZ}_{\text {INEPAN }}$ model developed in the Polish Academy of Sciences and E. Maczyńska's model, developed by Polish scientists and adapted to the Polish economy. The results confirm that these models are a valuable tool in assessing the financial condition of enterprises and allow for bankruptcy forecasting. Their application to companies listed on NewConnect, however,
\end{abstract}

(C) Copyright Institute of Economic Research \& Polish Economic Society Branch in Toruń

Date of submission: September 2, 2013; date of acceptance: March 8, 2014

* Contact: magdams@ug.edu.pl, Department of International Financial Markets, Institute of International Business, Faculty of Economics, University of Gdansk, ul. Armii Krajowej 119/121, 81-824 Sopot, Poland 
may be limited due to the specific profile of these entities as most of these enterprises are in fact newly formed and therefore the existing empirical data may prove insufficient.

\section{Introduction}

NewConnect (NC) is a market intended for equity securities trading. It was organized by Warsaw Stock Exchange and functions as an alternative trading system next to the main market. A specialised nature of NewConnect provides access for entities unable to meet the conditions set for issuers in the primary market. In practice, it allows for IPO by small companies, including start-ups, with no experience or history and conducting business primarily based on intangible assets. These internal regulations for issuers and companies listed on NewConnect, however, increase the risk for investors. The simplified procedure for listing and share issue, limited disclosure obligations as well as the specificity of companies listed on NewConnect limit the analytical tools used to assess companies listed on the main market.

In this paper, discriminant models for forecasting bankruptcy are used to analyse the financial situation of companies removed from NewConnect due to bankruptcy. The aim of this study is to evaluate the usability of early warning models in analysing the financial condition of companies listed in the alternative trading system.

\section{The nature and development of discriminant models for forecasting bankruptcy}

The interest in forecasting operational hazards for enterprises emerged in the United States at the beginning of the twentieth century (Mączyńska \& Zawadzki, 2006). The first studies on forecasting bankruptcy for economic entities were conducted in 1900 by Thomas Woodlock. The results of the analysis, concerning railway companies, were published in the article "The percentage of operational costs to gross retained earnings" (Karamzadeh, 2013). The global economic crisis of the 1920's and 1930's intensified the need for early warning analytical tools against bankruptcy. This research was undertaken, among others, by Winakor and Smith, who on the basis of financial data analysis of 183 companies in financial difficulty found that the most reliable indicator of predictive failure is a failing indicator of working capital in relation to total assets. In 1942, the analysis conducted 
by C.L. Merwin on a sample of 939 companies confirmed the effectiveness of this indicator in a period of 4-5 years before the bankruptcy. He found, however, that two other indicators should also be included, the current ratio and the equity to total liabilities ratio (Hasankhani et al., 2011).

A breakthrough in the studies on bankruptcy forecasting models came in the 1960's in the models developed by an American professor, Edward Altman. Altman is considered to be a precursor in the transition from onedimensional to multidimensional statistical methods of discriminant analysis as a tool for predicting bankruptcy (Mączyńska \& Zawadzki, 2006). To assess the financial situation of entities, the models of discriminant analysis utilize one synthetic indicator as a combination of a relatively small number of indicators and weights expressing the importance of these indicators in reflecting the condition of the company (Antonowicz, 2007). The first Altman's model (also called the Z-score model or indicator) was published in 1968. It is based on the discriminant analysis carried out on the basis of the financial statements of 66 companies, including 33 companies in good financial condition, and 33 at risk of bankruptcy. The experiment included only production companies. In developing the model, Altman selected 22 indicators based on their capability to assess the financial situation of a company. As a result, the number of indicators for further research was limited to the five best reflecting the financial situation of the company (Altman, 1968) (see: Table 1). The first Altman's model, however, applies only to companies listed on the capital markets, as one of the independent variables $\left(x_{4}\right)$ contains the market value of equity capital. For this reason, in 1983, Altman modified his model, replacing this value with the book value of equity (Altman \& Hotchkiss, 2005). As a result, Z-score may also be used to analyze the non-public entities. Another modification in 1990 was to exclude the revenues from sales/total assets variable, which at the same time affected the function parameters. This development was aimed at minimizing the industry-specific impact on the effectiveness of prediction. Therefore the modified Z-score can be used to assess non-production corporate bankruptcy. It also applies to the analysis of emerging markets (Altman, 2000) (see: Table 1). 


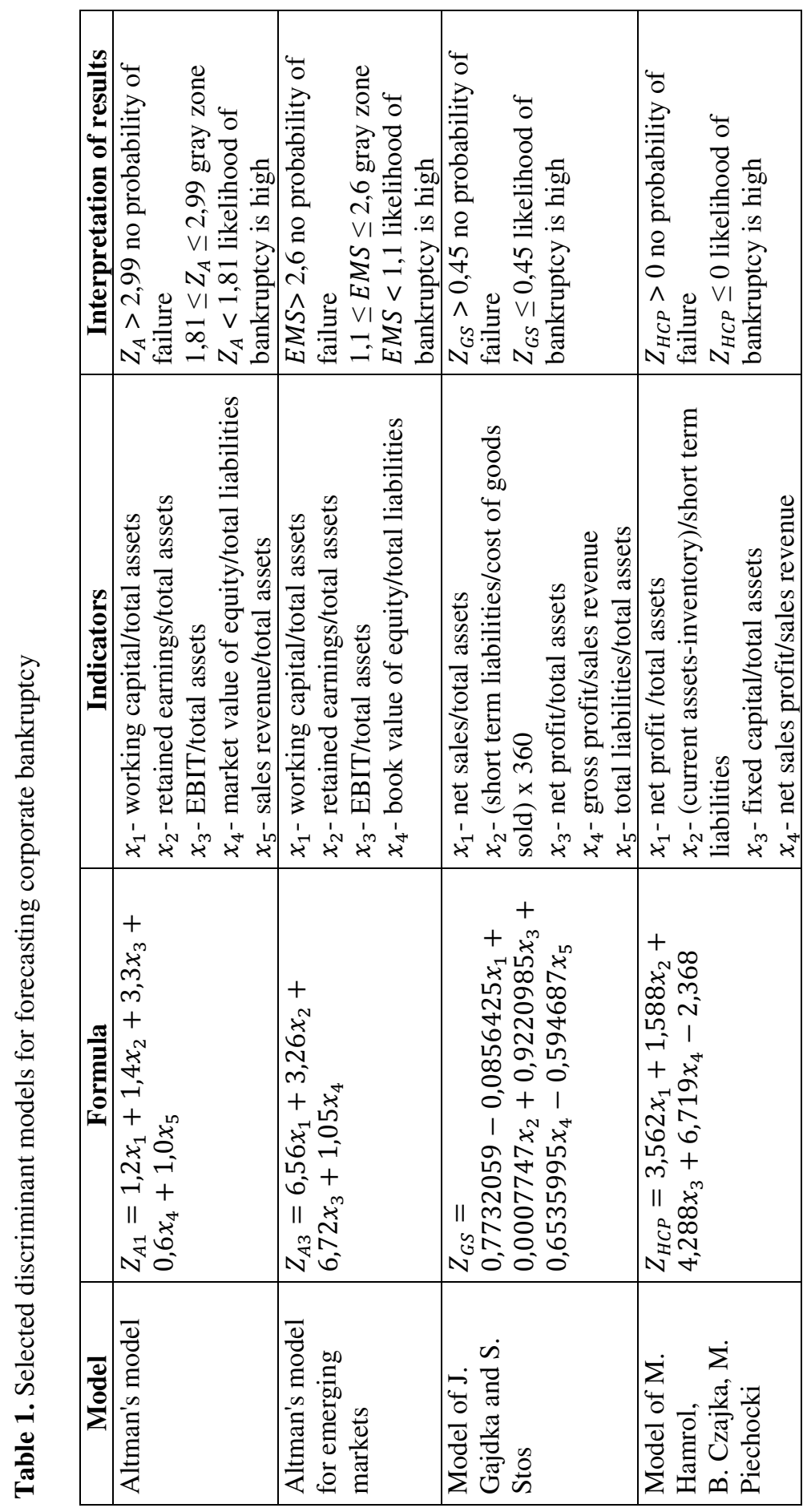




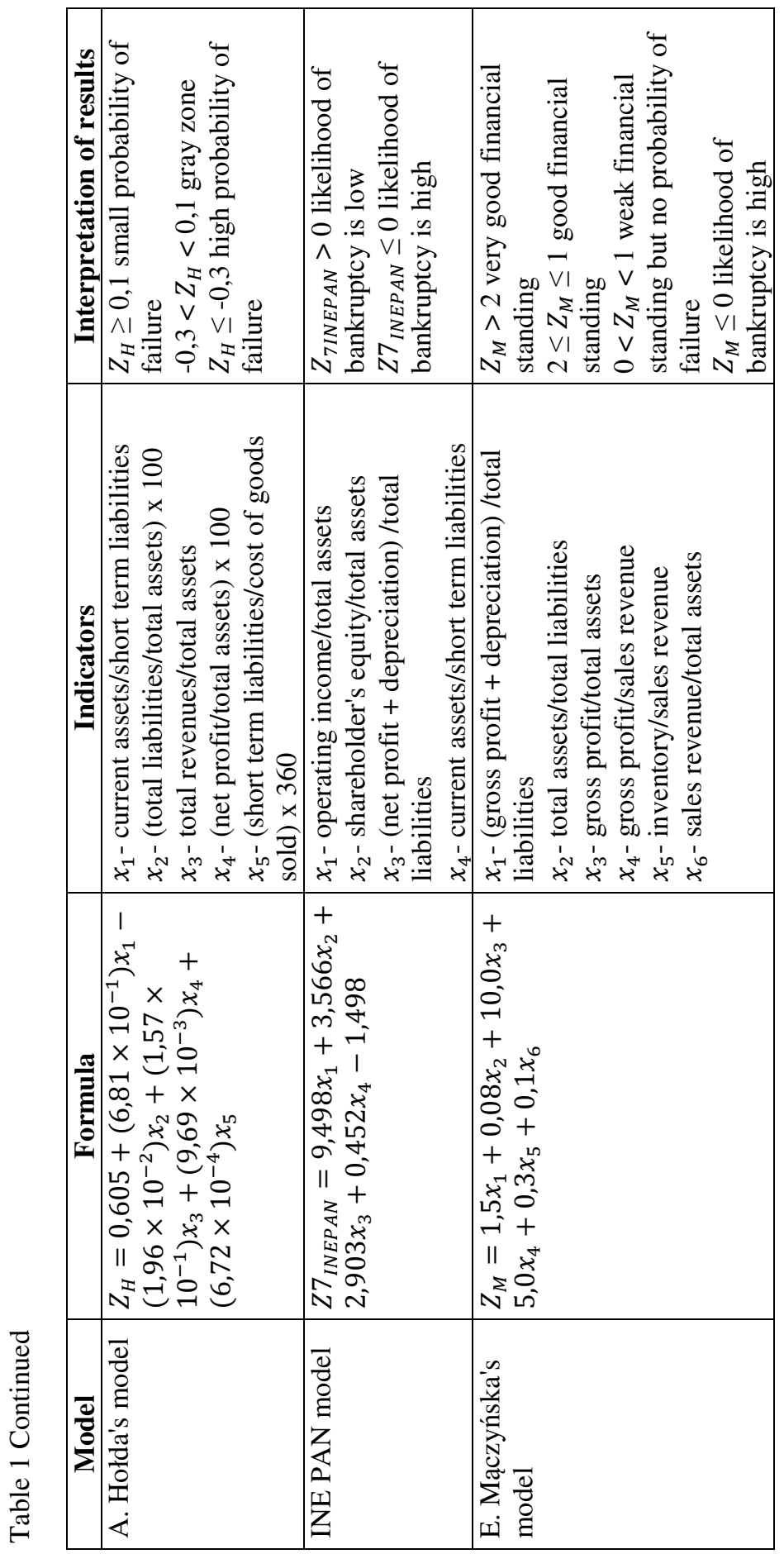




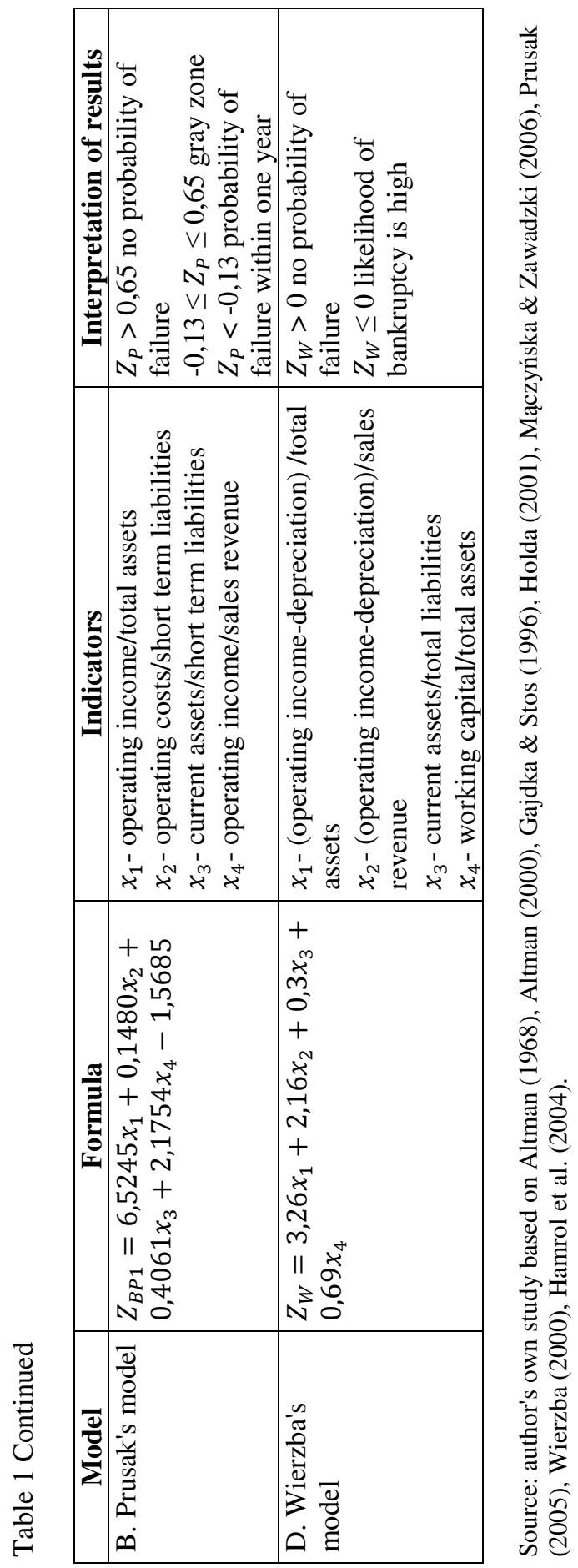


Altman's model is one of the most popular early warning models and to this day is successfully used by theorists and practitioners in many countries. It is emphasized in the literature on the subject, however, that this is not a universal model suitable for the evaluation of companies operating in different countries, and thus different economic conditions. As indicated by B. Prusak, limitations to the use of Altman's model arise from a number of its characteristics (Prusak, 2002; Prusak, 2004):

- As a statistical model, it shows high efficiency only in projections on a relatively homogeneous units to those that were used to estimate the model. It cannot, however, be considered that companies located in other countries were homogeneous to U.S. companies.

- Despite the existence of international or European accounting standards, there are still differences in the presentation of financial data, so the same financial ratios for the U.S. and other countries may be calculated differently.

- Due to the increased stability of the U.S. economy compared to other countries, Altman's model may have a higher prediction efficiency for the U.S. economy than in less predictable conditions, for example, for the Polish economy.

Similar observations on the application of Altman's model were also presented by A. Hołda. He notes that the conditions in which the empirical data was collected for the model change in time and therefore the usability of models based on historical data is limited in time. In addition, the use of discriminant functions should be limited to the country where data was collected for the development of the model, precisely because of the different environment in which businesses operate and the specificity of the accounting system (Hołda, 2001).

In Poland, the first attempts to build a discriminant model adequate to Polish economic conditions were undertaken after the change of the economic system, in the mid-1990s. Initially, the bankruptcy forecasting attempts were based on evaluating the effectiveness of Altman's model in the Polish economy by using it to analyze Polish companies, especially those listed on WSE. In most cases, researchers came to a similar conclusion that this model cannot be directly applied in the Polish conditions (Prusak, 2004).

One of the first models developed for the Polish economy were the models by Gajdka and Stos. In their study, the authors used data from 40 financial companies, half of which were assigned to the bankrupt entities group and the other half to the group of a stable financial condition. The analysis was based on the designation of 20 financial ratios, calculated on the basis of the financial statements from 1994 to 1995, of which five even- 
tually qualified for the model (see: Table 1). The accuracy of the predictions based on this model was 93\% (Gajdka \& Stos, 1996).

The research on the construction of discriminant functions was also carried out at the Institute of Economic Sciences of the Polish Academy of Sciences under the direction of E. Mączyńska. Analyses were performed on a sample of 80 companies listed on the Warsaw Stock Exchange (40 at risk of collapse, and 40 in good financial condition) using the financial statements of these entities for the years 1997 to 2001 and the data on their stock market value at the end of the first quarter of 2002. The authors have selected 45 indicators characterizing the dynamics of growth, profitability, debt, liquidity and operational efficiency of an enterprise (Mączyńska \& Zawadzki, 2006). It allowed for the creation of seven models that differed in the number of indicators used. Table 2 shows the form of the discriminant function and the indicators used in the $\mathrm{Z} 7_{\text {INEPAN }}$ model, characterized by high forecast efficiency ( $94.82 \%$ according to P. Antonowicz, see: Table 1). In addition, E. Mączyńska presented another early warning model (see: Table 2), an adaptation of Jacobs's function used by foreign financial institutions to assess the creditworthiness of companies (Bombiak, 2010).

Among other discriminant models used to predict corporate bankruptcy, it is worth to indicate models by A. Hołda (2001), B. Prusak (2005), D. Wierzba (2000) and the so-called Poznań model developed by M. Hamrol, B. Czajka and M. Piechocki (2004). The discriminant function formula, the indicators and the interpretations of results for these models are presented in Table 1.

The demand for early warning models using discriminant functions increases, especially in periods of rapid social and economic change. In response to these expectations, the researchers present further proposals or modify existing models in order to best adapt them to the changing operational conditions of the enterprises. Due to the increasing number of available predictive models, studies are also carried out to determine their effectiveness. A ranking of Z-score was created, among others, by P. Antonowicz (2007), based on the verification of 52 models (36 Polish and 16 foreign) on a sample of 208 Polish companies. The ten top rated models are shown in Table 2. In Antonowicz's ranking, two models, developed in the Polish Academy of Sciences, show best performance in forecasting bankruptcy among Polish companies. It is worth noting that all the models developed by Altman are also included in the first ten. Despite the criticism regarding the legitimacy of using models developed for the U.S. in the Polish economy, Antonowicz's research shows their high predictive ability in Polish conditions. 
Table 2. Enterprise bankruptcy forecasting models with the highest predictive ability according to P. Antonowicz

\begin{tabular}{|c|c|}
\hline Model & $\begin{array}{c}\text { Predictive accuracy of } \\
\text { the models }\end{array}$ \\
\hline Model $Z 7_{I N E P A N}$ & $94,82 \%$ \\
\hline Model $Z 6_{I N E} P A N$ & $94,20 \%$ \\
\hline Model $Z_{M}$ by E. Mączyńska & $94,11 \%$ \\
\hline Model $Z_{H C P}$ by M. Hamrol, B. Czajka, M. Piechocki & $93,78 \%$ \\
\hline Model $Z_{B 1}$ by B. Prusak & $92,52 \%$ \\
\hline Model $Z_{B 2}$ by B. Prusak & $91,81 \%$ \\
\hline Model $Z_{D W}$ by D. Wierzba & $91,71 \%$ \\
\hline Model $Z_{A 3}$ by E. I. Altman & $91,45 \%$ \\
\hline Model $Z_{A 1}$ by E. I. Altman & $89,73 \%$ \\
\hline Model $Z_{A 2}$ by E. I. Altman & $89,30 \%$ \\
\hline
\end{tabular}

Source: author's own study based on Antonowicz (2007, pp. 176-199).

The literature on the subject presents more and more studies aimed at verifying the effectiveness of bankruptcy forecasting models. The scope of the analysis presented is not as wide as in the case of Antonowicz's research. J. Kisielińska and A. Wyszkowski (2010) verified the bankruptcy forecasting efficiency of 17 Polish models, including 13 discriminant models and 4 logit models, using the financial data analysis of 16 companies listed on WSE ( 8 declared bankrupt and 8 in good financial condition). The efficiency of Polish models only was also examined by O. Rusek (2010). The author has analyzed 23 discriminant models, using the financial data of six companies listed on WSE, against which bankruptcy or liquidation proceedings were initiated in 2009 , or against which the court was requested for the initiation of such proceedings. The period of research (similarly to the previous model) covered the years 2003-2008. Discriminant models, based solely on the companies declared bankrupt, were also verified by G. Gołębiowski and K. Żywno (2008). The authors analyzed 25 Polish models and, additionally, Altman's model for emerging markets.

The results of individual studies differ in terms of evaluating the effectiveness of the models tested. Nonetheless, the authors support the usability of such models as analytical tools in assessing the financial condition of companies, provided that they are not considered a universal tool regarding their limitations. There is no single best model in terms of prediction efficiency. Obtaining a high-quality forecast requires an adequate model whose estimation properties are similar to those of the test subject. In addition, several discriminant models should be used in analysis, and changes in time 
value need to be observed. Such an approach increases the objectivity of the results achieved and allows to minimize one of the disadvantages of the models - a subjective selection of indicators to discriminant functions.

\section{Characteristics of NewConnect market}

NewConnect was established in August 2007 in order to minimize the financial gap in the limited access of small and medium-sized enterprises to various forms of capital raising. This market operates as a alternative trading system next to WSE. They are independent trading platforms, using only a common transaction system. In contrast to the main market, NewConnect is unregulated, which means that it does not comply with some national and EU regulations, and its operation is based mainly on the principles laid down by the organizer of the Alternative Trading System Rules and the current resolutions of the Management Board of the Warsaw Stock Exchange

In comparison to the main stock market, $\mathrm{NC}$ is characterized by simplified procedures for introduction and quotations of financial instruments, as well as lower fees. Companies planning to raise capital through the issue of shares on NewConnect need not meet the requirements for a minimum period of operation and capitalization. Issuers include entities commencing their activities as well as a companies with years of experience. No specific minimum capitalization opens NewConnect to companies of small and medium-sized businesses sector lacking significant assets and operating mainly based on intangible assets. With the creation of NewConnect, arouse the opportunity to trade financial instruments on WSE by the socalled private placement (addressed to a maximum of 149 investors), which is a much faster and less expensive procedure compared to the public offering (addressed to unlimited recipients). This method of financial instruments sale does not require the preparation prospectus and the approval of the Financial Supervisory Commission (FSC). Instead, issuers are preparing a much simpler information document, which is subject to approval by an Authorised Adviser of their choice. For companies listed on the NC, less requirements have been determined in terms of disclosure obligations and principles of good practice. With more liberal regulations, the process of issuing shares and the stock market quotations are definitely less expensive in comparison to the main market. The amount of fees the issuers are charged by the exchange is also lower on NewConnect (MosionekSchweda, 2011). 
Lesser issuer requirements of NewConnect allow several times more IPOs and at the same time effect in a much lower value of acquired equity in comparison to the main market. By the end of 2012, 458 companies had debuted on NewConnect, securing a total of about PLN 1.38 billion. At the same time, 172 issuers were admitted to trading on the main market securing in the new issue a total of over PLN 15.96 billion (see: Figure 1).

Figure 1. The number of IPOs and the value of the accumulated capital (PLN) on the main market and NewConnect from 30 August 2007 to 31 December 2012

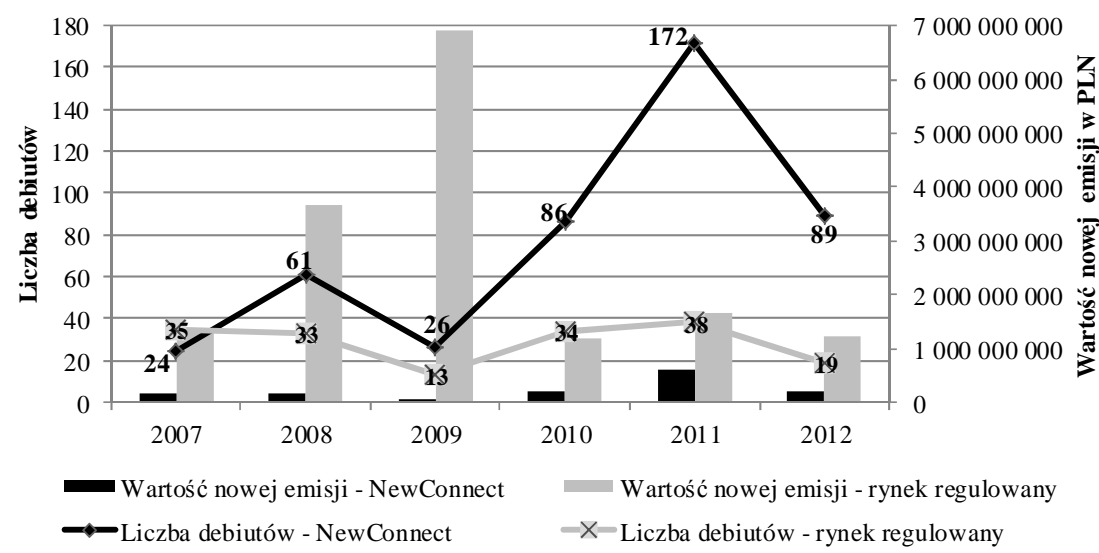

Source: author's own study based on data derived from portals www.gpw.pl and www.newconnect.pl.

NewConnect opened on the eve of the contemporary financial crisis resulting in, among others, declining indexes in global stock markets, limiting the activity of investors in the capital markets and the companies resigning from the issue for fear of too low valuations. The lack of stability in the financial markets affected the development of the Polish alternative market. The characteristic features of this market, primarily including a lesser regulatory regime which was originally an advantage, gradually became one of the barriers to its development. Increasing liquidity problems of $\mathrm{NC}$, the first bankruptcy declarations of companies listed and more frequent criticisms related to the market forced the WSE Management Board to make changes in the regulations for its operation. In 2012, financial penalties of up to PLN 20,000 imposed on unreliable issuers were introduced, as well as the obligation to produce the report on the state of the issuer for companies 
that experience financial problems or are to alter the scope of the business together with the increase in disclosure requirements and specifications regarding the content of the information documents. In order to protect the interests of investors, as well as increase market transparency and integrity of the issuers, WSE Management Board introduced two new segments for companies whose financial instruments show a high investment risk: NewConnect High Liquidity Risk and NewConnect Super High Liquidity Risk (Sudak, 2012; Chronowska, 2012). In the first allocation, 108 companies went to the HLR segment and 15 issuers to SHLR, representing more than $25 \%$ of all companies listed on NewConnect.

As a result of the changes, the messages of the WSE Management Board about the penalties imposed on issuers for not meeting the information obligations appear almost every day in the NewConnect news. In early 2013, the authorities informed about the subsequent changes in the ASO regulations, mainly related to companies planning to debut. Starting from 1 March 2013, at least 15\% of the shares of the company intending to enter NewConnect for the first time, must be in possession of at least ten shareholders, each of whom has no more than $5 \%$ of the total number of votes at the General Meeting. The duration of compulsory cooperation of companies with an Authorised Adviser was increased from one to three years (with the possibility of shortening to 12 months). In addition, financial penalties for non-compliance with the Regulations, introduced less than a year earlier, increased from PLN 20,000 to PLN 50,000 (Resolution No. 175/2013 of the Management Board of the Warsaw Stock Exchange S.A.).

Changes currently implemented to the rules of the NewConnect meet with various reactions of the stakeholders. For prospective issuers and listed companies, stricter regulations increase the costs of debut and listing. On the other hand, investors define these changes as introduced too late and still insufficient to ensure the safety of funds invested in NC and the quality of the companies listed there.

\section{Use of discriminant models for the analysis of companies listed on NewConnect}

Despite a short period of operation, NewConnect have already noted first bankruptcies. So far, for this reason, the Management Board of the Warsaw Stock Exchange removed quotations of four companies: Perfect Line S.A., Promet S.A., InwazjaPC S.A. and Budostal-5 S.A. Another seven have been removed because of a flagrant violation of the ASO rules, which in the opinion of the NewConnect organizer posed a serious threat to the in- 
terests and security of the participants in the market. The article uses the financial data of the above companies to assess the applicability of the discriminant models to predict bankruptcy of companies listed on NewConnect. The analysis of three models, including two developed for the Polish economy, having the largest capacity of prediction according to the ranking of P. Antonowicz ( $\mathrm{Z}_{\text {INEPAN }}$ model and E. Mączyńska's model) as well as Altman's model for emerging markets. The financial data comes from the financial statements of the surveyed enterprises. As the companies debuting on NewConnect prepare a simplified information document (instead of the prospectus) and do not have the obligation to include financial statements, in most cases it is not possible to acquire financial data older than a year before the IPO.

The first discontinued listing due to bankruptcy took place in December 2009 and pertained to Perfect Line S.A. This company was listed on the NC on 24 April 2008 rather unsuccessfully. The issuer planned to receive approximately PLN 5-6 million from the issuance and eventually managed to accumulate only PLN 650,000 from the market with the shares acquired by four investors only, including the Authorised Adviser cooperating with the company. Although not an entirely successful issue, the managers of the company were not to renounce the established development plans. The increase in employment, the change of registered office, large investments in the expansion of fixed assets, and therefore the increase in external financing in the capital structure of the company, with declining orders for its services, meant that Perfect Line not only failed to achieve its objectives, but ceased to exist through liquidation (Pochmara, 2009). In April 2009, the Management Board applied to court for a bankruptcy declaration. A resolution on this matter was issued a month later and Perfect Line shares were removed from trading on NewConnect on 2 December 2009 (Resolution No. 663/2009).

Table 3. The results of Altman's model, $\mathrm{Z} 7_{\text {INEPAN }}$ model and Mączyńska's model for Perfect Line S.A.

\begin{tabular}{|c|c|c|c|}
\hline Year of analysis & Altman's model & Model Z7 INE PAN $_{\text {Mączyńska's }}$ & $\begin{array}{c}\text { Model } \\
\text { model }\end{array}$ \\
\hline 2007 & 3,26 & 2,19 & 2,96 \\
\hline 2008 & $-4,11$ & $-4,99$ & $-3,35$ \\
\hline $2009 *$ & $-48,80$ & $-34,68$ & $-28,19$ \\
\hline
\end{tabular}

* Data based on the financial statements as of 5 May 2009.

Source: author's own study based on the financial statements of the company. 
Table 3 shows the results of the assessment of the financial condition of Perfect Line S.A. based on three discriminant models. For this analysis, the data published by the company in the years 2007-2009 has been used. The results obtained are consistent; the year before their debut on the stock market, each model classifies the audited company as not threatened with bankruptcy. The situation changes in 2008, when all indicators are negative, showing the financial problems of the subject and even worsen in the year of declaring bankruptcy.

Two years after the fall of Perfect Line S.A. in December 2011, the WSE Management Board decided to discontinue the listing of another company, Promet S.A. (Resolution No. 1565/2011). The company debuted on $\mathrm{NC}$ on 31 March 2010 and its quotations grew at an impressive rate from the date of the debut with the closing price higher by $80 \%$ than the issue price. By the end of 2010, quotations increased by $400 \%$ and the capitalization reached the peak of more than PLN 35 million. In the first half of 2011, however, one of the three leading shareholders of the company sold off, Promet S.A., was allegedly exposed to a loss of PLN 3.5 million, debt service was suspended, and in June, the Management Board filed for bankruptcy with the court decision issued on 23 September 2011.

Table 4. The results of Altman's model, $\mathrm{Z} 7_{\text {INEPAN }}$ model and Mączyńska's model for Promet S.A.

\begin{tabular}{|c|c|c|c|}
\hline Year of analysis & Altman's model & Model Z7 $_{\text {INE PAN }}$ & $\begin{array}{c}\text { Mączyńska's } \\
\text { model }\end{array}$ \\
\hline 2009 & 20,77 & 3,23 & $-0,71$ \\
\hline 2010 & 5,46 & 3,66 & 3,10 \\
\hline $2011^{*}$ & $-13,31$ & $-14,73$ & $-14,26$ \\
\hline
\end{tabular}

* Data based on the financial statements at 30 June 2011.

Source: author's own study based on the financial statements of the company.

Table 4 shows the results of the Promet S.A. financial situation analysis. In this case, neither Altman's model nor the model developed by researchers at the Polish Academy of Sciences forecast the bankruptcy within two years and the year before its declaration. Slightly different results were obtained using E. Mączyńska's model as Z-indicator calculated for 2009 takes a negative value showing the risk of bankruptcy. In turn, the calculated rate for 2010 indicates a very good financial condition of the entity. Authors of many studies on verifying the efficiency of early warning models note that the effectiveness of these models increases with the onset of bankruptcy. In the analysed case the only warning about the deteriorating 
situation of the company was shown on the basis of Altman's model, in which we observe a significant decrease in values of Z-score, while it is still at the so-called safe zone level.

The third company on NC to declare bankruptcy was Budostal-5 S.A. Against the background of the other enterprises analyzed in this study, it is distinguished by a very long history of operation, dating back to 1949. The company was involved in the construction and modernization of a number of significant facilities in Malopolska region. It achieved the best financial results in 2007, achieving sales revenues of PLN 150 million and PLN 4 million net profit. The company's financial problems began after the signing of a seemingly advantageous contract in 2008, worth about PLN 100 million for the renovation of the provincial road No. 776. The increase in prices of raw materials (approximately 73\%) significantly affected the situation of the company, as it was to bear the cost increases according to the contract (Paluch, 2012). Despite the financial difficulties the company authorities carried out a share issue worth PLN 2.2 million and on 24 June 2010 Budostal-5 made its debut on NewConnect. In 2011, the company reported more than PLN 60 million net loss and on 30 December 2011 filed to the Krakow court to declare bankruptcy open to arrangement. At the end of February 2012, the company received the decision of the court in accordance with the request. Three months later, the court decided, however, to change the mode of bankruptcy proceedings to liquidation. On the 7 January 2013, the listing of Budostal-5 was discontinued on NewConnect (Resolution No. 5/2013).

Table 5. The results of the Altman's model, $\mathrm{Z} 7_{\text {INEPAN }}$ model and Mączyńska's model for Budostal-5 S.A.

\begin{tabular}{|c|c|c|c|}
\hline Year of analysis & Altman's model & Model Z7 INE PAN $_{\text {PAczyńska's }}$ & $\begin{array}{c}\text { Mączodel } \\
\text { model }\end{array}$ \\
\hline 2008 & 1,97 & 0,34 & 0,65 \\
\hline 2009 & $-2,06$ & $-2,46$ & $-2,74$ \\
\hline 2010 & 0,83 & 0,94 & 1,21 \\
\hline 2011 & $-20,20$ & $-17,26$ & $-18,45$ \\
\hline $2012^{*}$ & $-19,25$ & $-8,50$ & $-21,27$ \\
\hline
\end{tabular}

* Data based on the financial statements as of 30 September 2012.

Source: author's own study based on the financial statements of the company.

The results of the discriminant analysis for Budostal-5 S.A. are shown in Table 5. In this analysis, Altman's model proves to be the most efficient showing that the risk of bankruptcy occurred from 2009 onwards. The val- 
ue of the index for 2008 classifies the company as the so-called gray area in which a clear evaluation is not possible. The models developed by Polish scientists give slightly different results, as Z-score indicators calculated for the data of 2008 and 2010 do not predict the financial difficulties of the company. In particular, the results obtained on the basis of E. Mączyńska's model in 2010, a year before filing for bankruptcy, indicate that the company is in good financial condition.

The last bankrupt company on NewConnect so far was InwazjaPC S.A. The Board filed for bankruptcy in less than a year since its debut on the market on 30 March 2012 (the company listed on 5 April 2011). The application indicated insolvency resulting from failure to perform outstanding liabilities as the reason. The loss of liquidity of the company resulted from a drop in sales by $70 \%$ due to the disruption of deliveries from manufacturers of computer hardware, the main trading product of InwazjaPC (it was caused by flooding in Thailand, where significant part of the company's major suppliers of components was based) (Zbiejcik, 2012). The Management Board of the company applied for bankruptcy open to arrangement, the court, however, decided otherwise and liquidation proceedings were declared on 22 May. NC discontinued listing of InwazjaPC S.A. on 21 January 2013 (Resolution No. 62/2013).

Table 6. The results of Altman's model, $Z 7_{\text {INEPAN }}$ model and Mączyńska's model for InwazjaPC S.A.

\begin{tabular}{|c|c|c|c|}
\hline Year of analysis & Altman's model & Model Z7 INE PAN $_{\text {Paczyńska's }}$ & $\begin{array}{c}\text { Mączol } \\
\text { model }\end{array}$ \\
\hline $2011^{*}$ & $-5,13$ & $-5,29$ & $-4,38$ \\
\hline $2012 * *$ & $-6,80$ & $-4,91$ & $-4,95$ \\
\hline
\end{tabular}

* Data based on the financial statements from 30 August 2010 to 31 December 2011.

** Data based on the financial statements as of 30 March 2012.

Source: author's own study based on financial statements of the company.

Table 6 shows the results of the analysis conducted for InwazjaPC S.A. It is difficult to discuss the legitimacy of discriminant models due to the very short period of operation of the entity. The company was established in August 2010. The first financial statements of the entity covered the period from the establishment until the end of 2011. Data for 2012 refers only to the first quarter. Ratios calculated on the basis of the available data clearly classify the company as an entity at the risk of bankruptcy. 


\section{Conclusions}

The above analytical results obtained by using discriminant models on the financial data of companies that discontinued listing on NewConnect confirm that forecasting a business failure cannot be based on the results of only one model. It should also be noted that although Altman's model is the oldest among the models used in this study and does not address the specificity of the Polish economy, it achieved better results in the case of Budostal-5 S.A. than models adapted to the realities of the Polish economy developed by Polish scientists.

Numerous pieces of research verifying the effectiveness of discriminant models confirm that they are a valuable tool for checking the financial condition of companies and allow to forecast the risk of bankruptcy. The application of these models to companies listed on NewConnect, however, may be difficult due to the specific profile of these entities, as most of them are newly formed companies with no empirical data available.

\section{References}

Altman E.I. (1968), Financial ratios, discriminant analysis and the prediction of corporate bankruptcy, "Journal of Finance", Vol. 23, No. 4, http://dx.doi.org/ $\underline{10.2307 / 2978933}$.

Altman E.I. (2000), Predicting financial distress of companies: revisiting the ZScore and Zeta ${ }^{\circledR}$ models, http://pages.stern.nyu.edu/ ealtmanPredFnclDistr.pdf (15.02.2013).

Altman E.I., Hotchkiss E. (2005), Corporate Financial Distress and Bankruptcy, Predict and Avoid Bankruptcy, Analyze and Invest in Distressed Debt, John Wiley \& Sons, Inc., Hoboken, New Jersey.

Antonowicz P. (2007), Metody oceny i prognozowania kondycji ekonomicznofinansowej przedsiębiorstw, ODDK, Gdańsk.

Bombiak E. (2010), Modele dyskryminacyjne jako metoda oceny sytuacji finansowej przedsiębiorstwa, „Zeszyty Naukowe Akademii Podlaskiej w Siedlcach”, No. 86.

Chronowska E. (2012), New segments on NewConnect, http://www.ncbiuletyn.pl /czytaj/1306_nowe_segmenty_na_newconnect.html (15.02.2013).

Gajdka J., Stos D. (1996), Wykorzystanie analizy dyskryminacyjnej w ocenie kondycji finansowej przedsiębiorstw [in:] R. Borowiecki (ed.), Restrukturyzacja w procesie przeksztatceń i rozwoju przedsiębiorstw, Akademia Ekonomiczna w Krakowie, Kraków.

Gołębiowski G., Żywno K. (2008), Weryfikacja skuteczność modeli dyskryminacyjnych na przyktadzie wybranych spótek giełdowych, "Contemporary Economics", No. 3. 


\section{Magdalena Mosionek-Schweda}

Hasankhani E., Sheikhi M.R., Garshasbi Y., The Ability to Predict Firms'bankruptcy Using Financial Ratios, "Australian Journal of Basic and Applied Sciences", No. 5(7).

Hamrol M., Czajka, B., Piechocki M. (2004), Upadłości przedsiębiorstwa - model analizy dyskryminacyjnej, „Przegląd Organizacji”, No. 6.

Hołda A. (2001), Prognozowanie bankructwa jednostki $w$ warunkach gospodarki polskiej $z$ wykorzystaniem funkcji dyskryminacyjnej $Z_{H}$, „Rachunkowość”, No. 5.

Karamzadeh M.S. (2013), Application and Comparison of Altman and Ohlson Models to Predict Bankruptcy of Companies, "Research Journal of Applied Sciences, Engineering and Technology", No. 5(6).

Kisielińska J., Waszkowski A. (2010), Polskie modele do prognozowania bankructwa przedsiębiorstw $i$ ich weryfikacja , ,Zeszyty Naukowe SGGW, Ekonomika i Organizacja Gospodarki Żywnościowej”, No. 82.

Mączyńska E., Zawadzki M. (2006), Dyskryminacyjne modele predykcji bankructwa przedsiębiorstw, "Ekonomista", No. 2.

Mosionek - Schweda M. (2011), Wykorzystanie alternatywnych systemów obrotu jako źródta finansowania rozwoju matych i średnich przedsiębiorstw [in:] Balcerzak A., Moszyński M. (ed.), Spin off, spin out jako instrument budowania przedsiębiorczości akademickiej oraz stymulowania innowacyjności regionu, Polskie Towarzystwo Ekonomiczne Oddział w Toruniu, Torun.

Paluch, M. (2012), Kraków: Budostal-5 na skraju bankructwa, „Gazeta Krakowska”, http://www.gazetakrakowska.pl/artykul/491567,krakow-budostal-5-naskraju-bankructwa,id,t.html (20.02.2013).

Pochmara P. (2009), Czy likwidację Perfect Line można byto przewidzieć? http://www.ipo.pl/new_connect/artykuly/czy_likwidacje_perfect_line_mozna_ bylo_przewidziec_592552.html (15.02.2013).

Prusak B. (2002), Altman raz jeszcze, Wydział Zarządzania i Ekonomii, Politechnika Gdańska, Gdańsk.

Prusak B. (2004), Jak rozpoznać potencjalnego bankruta? [in: ] F. Bławat (ed.), Prace Naukowe Katedry Ekonomii $i$ Zarzadzania Przedsiębiorstwem, t. 3, Wydawnictwo Politechniki Gdańskiej, Gdańsk.

Prusak B. (2005), Nowoczesne metody prognozowania zagrożenia finansowego przedsiębiorstw, Difin, Warszawa.

Rusek O. (2010), Przydatność modeli dyskryminacyjnych $w$ zarzadzaniu przedsiębiorstwem, „Zeszyty Naukowe SGGW, Ekonomika i Organizacja Gospodarki Żywnościowej”, No. 85.

Sudak I. (2012), Giełda bierze się za patologie na rynku NewConnect, http://wyborcza.biz/Gieldy/2029020, 114,507.12033632. Html (15.02.2013).

Resolution No. 175/2013 of the Management Board of the Stock Exchange in Warsaw S.A. of 13 February 2013 on the amendment of the Alternative Trading System Rules, News Archive, http://www.newconnect.pl (15.02.2013).

Resolution No. 62/2013 of the Management Board of the Stock Exchange in Warsaw S.A. dated 15 January 2013 concerning the exclusion of the alternative 
trading system shares of InwazjaPC S.A. in liquidation, News Archive, http://www.newconnect.pl (15.02.2013).

Resolution No. 5/2013 of the Management Board of the Stock Exchange in Warsaw S.A. of 2 January 2013 on the exclusion of the alternative trading system of financial instruments of the company Budostal-5 S.A. in liquidation, News Archive, http://www.newconnect.pl (15.02.2013).

Resolution No. 1565/2011 of the Management Board of the Stock Exchange in Warsaw S.A. of 27 December 2011 on exclusion of shares of Promet S.A. in liquidation in the alternative trading system on the NewConnect, News Archive, http://www.newconnect.pl (15.02.2013).

Resolution No. 663/2009 of the Management Board of the Stock Exchange in Warsaw S.A. of 25 November 2009, News Archive, http://www.newconnect.pl (15.02.2013).

Wierzba D. (2000), Wczesne wykrywanie przedsiębiorstw zagrożonych upadtościq na podstawie analizy wskaźników finansowych - teoria i badania empiryczne, „Zeszyty Naukowe, Wyższa Szkoła Ekonomiczno-Informatyczna w Warszawie", No. 9.

Zbiejcik M. (2012), InwazjaPC do likwidacji, jest postanowienie sadu, http://wiadomosci.stockwatch.pl/inwazjapc-do-likwidacji-jest-postanowieniesadu, shares, 25,909 (15.02.2013). 